\title{
PRIVATE CONSUMPTION, NON-TRADED GOODS AND REAL EXCHANGE RATE: A COINTEGRATION-EULER EQUATION APPROACH
}

Kenneth S. Lin

Working Paper 5731

\author{
NATIONAL BUREAU OF ECONOMIC RESEARCH \\ 1050 Massachusetts Avenue \\ Cambridge, MA 02138 \\ August 1996
}

This paper was presented at the NBER East Asian Seminar on Economics. This work is part of the NBER's project on International Capital Flows which receives support from the Center for International Political Economy. I thank Professor Ching-Sheng Mao and participants in the Seminar for helpful discussions on an earlier draft. I also thank Professors Takatoshi Ito and Gian Maria Milesi-Ferretti whose comments led to an improvement of the paper, and Ms. Chia-Wei Hong for excellent research assistance. Any opinions expressed are those of the author and not those of the National Bureau of Economic Research.

(C) 1996 by Kenneth S. Lin. All rights reserved. Short sections of text, not to exceed two paragraphs, may be quoted without explicit permission provided that full credit, including $\mathcal{C}$ notice, is given to the source. 


\title{
PRIVATE CONSUMPTION, NON-TRADED \\ GOODS AND REAL EXCHANGE RATE: \\ A COINTEGRATION-EULER EQUATION \\ APPROACH
}

\begin{abstract}
This paper presents an empirical study of real exchange rate movements from a consumer's perspective. Trade between two countries creates a link between real exchange rate and terms of trade. It is the private consumption of non-traded goods that induces an equilibrium relationship between real exchange rate and private consumption of traded and non-traded goods. We use Ogaki and Park's (1989) cointegration-Euler equation approach to explore long-run implications from the equilibrium relationship. Given the stationary preference shocks assumption, the testable restriction is that real exchange rate and private consumption of traded and non-traded goods in the home and foreign countries are cointegrated. The empirical evidence suggests that private consumption in the home and foreign countries accounts for a significant fraction of the long run movements of real exchange rate in South Korea and Taiwan. Accounting for real government consumption does not overturn the result.
\end{abstract}

Kenneth S. Lin

Department of Economics

National Taiwan University

21, Hsu-Chou Road

Taipei

TAIWAN 


\section{Private Consumption, Non-Traded Goods and Real Exchange Rate: A Cointegration-Euler Equation Approach ${ }^{1}$}

Kenneth S. Lin

\section{Introduction}

This paper presents an empirical study of real exchange rate movements from consumer's perspective. For the private agent's intertemporal optimal choice of consumption, the marginal rate of substitution for the consumption of two goods must equal the corresponding relative price. Real exchange rate is the relative price of the home country's consumption basket in terms of the foreign country's consumption basket. Trade between two countries creates a link between real exchange rate and terms of trade. It is the private consumption of non-traded goods that induces an equilibrium relationship between real exchange rate and private consumption of traded and non-traded goods.

As displayed in Figures 1 and 2, private consumption in different countries and the bilateral real exchange rate all exhibit clear trends and have different fluctuations. Large, persistent movements of real exchange rate and small cross-country correlation of aggregate private consumption have been separate research topics in international macroeconomics. But surprisingly few attempted to account for the comovement between private consumption in different countries and real exchange rate both in the short run and in the long run.

One exception is Backus and Smith (1993). They studied a dynamic exchange economy with one traded good, one non-traded good for each country, and an arbitrary number of countries. One main theoretical finding is that fluctuations in aggregate consumption ratio between foreign country and home country and fluctuations in bilateral real exchange rate have similar dynamics and are positively correlated over time. However, based upon eight OECD countries, they found little evidence for the positive correlation in the time series data. There are two possibilities for the discrepancy between theory and evidence. First, preference shocks are

1 This paper was presented at the NBER East Asian Seminar on Economics. This work is part of the NBER's project on International Capital Flows which receives support from the Center for International Political Economy. I thank Professor Ching-Sheng Mao and participants in the Seminar for helpful discussions on earlier draft. I also thank Professors Takatoshi Ito and Gian Maria Milesi-Ferretti whose comments led to an improvement of the paper, and Ms. Chia-Wei Hong for excellent research assistance. 
not admitted in their model. When endowment shock is the sole external shock, it can only generate positive correlation between changes in the consumption ratio and changes in the real exchange rate. Second, agents have identical preferences across countries.

In this paper, we adopt the Ogaki and Park's (1989) cointegrationEuler equation approach to explore long-run implications from the equilibrium relationship between real exchange rate and consumption of various goods in different countries. Given the assumption of stationary preference shocks, one testable restriction on the long run movements of these variables is that they have similar trend properties in the sense that they are cointegrated. Here preference shocks not only induce negative correlation between real exchange rate and consumption in different countries, but also provide an identifying assumption. Preference parameters and weights assigned to non-traded goods in the construction of price index determine the similarity via elements in the theoretical cointegrating vector. Heterogeneous preferences across countries induce dissimilarity. When agents' preferences and weights used in the construction of price index are identical across the two countries, the real exchange rate becomes positively related to the cross-country consumption disparity in traded goods, but negatively related to the cross-country consumption disparity in non-traded goods. ${ }^{2}$

There is very little empirical evidence that any known fundamentals have reliable effects on the real exchange rate. Most previous studies on real exchange rate movements were taken from producer's perspective. ${ }^{3}$ And the most popular hypothesis is originated by Balassa (1964) and Sameulson (1964). It states that real exchange rate movements reflect the crosscountry difference in the productivity differential between traded and nontraded sectors. Since significantly higher productivity growth in the traded sector is expected to occur in the export-led growth economies, the positive relation between real exchange rate and cross-country disparity in productivity growth should be evident in those economies. The real exchange rate has been a natural indicator of export competitiveness. Establishing the positive relation and underlying growth mechanism has become a central research topic in economic development (For example, Ito, Issard and Symansky (1996))

\footnotetext{
2 Lucas (1982) also studied a two-country model in which the representative agent rank the exportable goods and importable goods according to its preferences and must use currency to purchase the goods. The relative price of between these two goods is determined by the cross-country difference in the endowments of these two goods.

3 Examples include Alder and Lehman (1983), Hsieh (1982), Huizinga (1987), Ito, Isard and Symsnsky (1996), Kravis and Lipsey (1987) and Strauss (1996).
} 
Adler and Lehman (1983) found that the real exchange rate contains a stochastic trend, and argued that this might be due to the productivity growth biased toward traded sector. Hsieh's (1982) study provided evidence for the role of productivity differential without explicitly modelling the non-stationarity of productivity differential and real exchange rate. Recently, Strauss (1996) found that a cointegrating relationship exists between real exchange rate and productivity differentials between traded and non-traded goods. Even though productivity differentials can account for a significant fraction of the long-run movement of real exchange rate, it seems a much higher productivity growth rate in the traded sector would be required to justify the long-run movement of real exchange rate. Recently, Froot and Rogoff (1991) took an alternative approach in the explanation of real exchange rate movement. They found that the cross-country difference in government spending can account for the real exchange rate movement. Since government consumption is concentrated in the purchase of non-traded goods, an increase in government consumption increases the relative price of non-traded goods to traded goods. Thus, the real exchange rate appreciates in the country with a high growth rate of government consumption.

As documented in Backus, Kehoe and Kydland (1992), cross-country correlation of output is larger than such correlation of consumption and productivity shocks for many industrial countries. In a single goods economy, however, the shocks produce output fluctuations that are less highly correlated than fluctuations in consumption and productivity shocks. To account for this discrepancy between theory and evidence, recent studies have introduced the non-separable utility function (Devereux et al. (1992)), and the incomplete markets (Kollmann (1991)) in the model. When the consumption basket in each country contains the non-traded component, the cross-country correlation of aggregate consumption could be less imperfect if that of non-traded goods consumption is less imperfect. This is so simply because countries do not share but consume their own non-traded goods. That is, the non-traded goods can account for small cross-country correlation of consumption.

The remainder of the paper is organized as follows. In section 2 , we derive the stationarity restriction on the trend properties of real exchange rate and private consumption from the Euler equation for the agent's intertemporal optimization problem. These restrictions are the foundation for the cointegration Euler Equation approach. In section 3, we describe the econometric specifications concerning the trend property of individual 
series like private consumption of traded and non-traded goods and their implications for the stationarity restriction. Section 4 explains the data and reports empirical results. The countries under consideration include Japan, South Korea, Taiwan and United States. Japan, Taiwan and South Korea ran huge trade surplus with United States, while Taiwan and South Korea ran significant trade deficits with Japan. Two sets of bilateral relations are examined with South Korea and Taiwan each serving as the home country. The bilateral real exchange rates exhibit different trend properties, and there is the cross-country disparity in private consumption. It is interesting to know the role of private consumption and non-traded goods in accounting for the long run movements of real exchange rate in South Korea and Taiwan. The last section contains concluding remarks.

\section{A Cointegration-Euler Equation Approach}

Consider two countries in a large world economy. Imagine that each economy is populated with an infinitely-lived representative household. The household in the home country in period $t$ is endowed with $X_{t}^{*}$ units of exportable goods, $Y_{t}^{*}$ units of importable goods and $Z_{t}^{*}$ units of non-traded goods. Goods $X_{t}$ and $Y_{t}$ are costlessly traded in the world markets, while $Z_{t}$ is only traded domestically.

The household ranks its consumption stream, $\left\{\left(X_{t} Y_{t} Z_{t}\right)^{\prime}, t \geq 0\right\}$ according to its lifetime utility function:

$$
E_{0}\left[\sum_{t=0}^{\infty} \beta^{t} U\left(X_{t}, Y_{t}, Z_{t}\right)\right]
$$

in which $\beta$ is a constant discount factor with $0<\beta<1$, and $E_{t}$ denotes the mathematical expectation conditioning on the information set available at the beginning of time $t, \Omega_{t}$. The intra-period utility function, $U\left(X_{t}, Y_{t}, Z_{t}\right)$, is assumed to take the form:

$$
U\left(X_{t}, Y_{t}, Z_{t}\right) \equiv \sigma_{x t} \frac{X_{t}^{1-\alpha_{x}}-1}{1-\alpha_{x}}+\sigma_{y t} \frac{Y_{t}^{1-\alpha_{y}}-1}{1-\alpha_{y}}+\sigma_{z t} \frac{Z_{t}^{1-\alpha_{z}}-1}{1-\alpha_{z}} .
$$

Here $\alpha_{i}>0$, for $i=x, y, z$, and preference shocks are allowed to influence the household utility via the stationary processes: $\left\{\sigma_{x t}, \sigma_{y t}, \sigma_{z t}, t \geq 0\right\}$.

Let $P_{x t}, P_{y t}$ and $P_{z t}$ be the prices of exportable goods, importable goods and non-traded goods in period $t$ measured in units of domestic currency, respectively. Let $b_{t+1}$ be the real value of international asset carried from period $t$ to period $t+1$ measured in units of exportables 
and let $r_{t}$ be the real interest rate measured in units of exportables. The household's budget constraint at time $t$ is

$$
b_{t+1}=\frac{P_{z t}}{P_{x t}}\left(Z_{t}^{*}-Z_{t}\right)+\frac{P_{y t}}{P_{x t}}\left(Y_{t}^{*}-Y_{t}\right)+\left(X_{t}^{*}-X_{t}\right)+\left(1+r_{t-1}\right) b_{t}
$$

The representative agent's intertemporal optimization problem is to maximize the lifetime utility function subject to the budget constraint, and the necessary first-order conditions for this problem are

$$
\begin{gathered}
\frac{\partial U}{\partial Y_{t}}=\frac{P_{y t}}{P_{x t}} \frac{\partial U}{\partial X_{t}}, \\
\frac{\partial U}{\partial Z_{t}}=\frac{P_{z t}}{P_{x t}} \frac{\partial U}{\partial X_{t}}, \\
E_{t}\left[\beta \frac{\partial U}{\partial X_{t+1}}\left(1+r_{t}\right)-\frac{\partial U}{\partial X_{t}}\right]=0
\end{gathered}
$$

and the budget constraint holds. Under our specification of the intra-period utility function, Euler equations in the first-order conditions can be expressed as

$$
\begin{aligned}
& \frac{\sigma_{x t} X_{t}^{-\alpha_{x}}}{\sigma_{y t} Y_{t}^{-\alpha_{y}}}=\frac{P_{x t}}{P_{y t}} \\
& \frac{\sigma_{z t} Z_{t}^{-\alpha_{z}}}{\sigma_{x t} X_{t}^{-\alpha_{x}}}=\frac{P_{z t}}{P_{x t}} .
\end{aligned}
$$

Taking the natural logarithm on both sides of the above equations yields

$$
\begin{aligned}
& p_{x t}-p_{y t}+\alpha_{x} x_{t}-\alpha_{y} y_{t}=u_{y t}, \\
& p_{x t}-p_{z t}+\alpha_{x} x_{t}-\alpha_{z} z_{t}=u_{z t},
\end{aligned}
$$

where $x_{t} \equiv \log X_{t}, y_{t} \equiv \log Y_{t}, z_{t} \equiv \log Z_{t}, p_{i t} \equiv \log P_{i t}$, for $i=x, y, z$, and $u_{i t}=\log \sigma_{x t}-\log \sigma_{i t}$, for $i=y, z$. In equilibrium, prices and consumption must satisfy equations (1) and (2).

If $u_{i t}$ is stationary for $i=y, z$, then equations (1) and (2) imply the stationarity of both $p_{x t}-p_{y t}+\alpha_{x} x_{t}-\alpha_{y} y_{t}$ and $p_{x t}-p_{z t}+\alpha_{x} x_{t}-\alpha_{z} z_{t}$. This restriction allows for different trend properties of consumption of various goods, depending upon preference parameters. For example, when $\alpha_{i}>\alpha_{x}$, the restriction allows goods $i$ consumption to grow at a slower rate than goods $X$ consumption for any given path of relative price and preference shocks and $i=y, z$. This is because a given change in $p_{i t}-p_{x t}$ induces a 
greater response of goods $i$ consumption. Suppose that general price index in home country is described by

$$
p_{t}=\theta_{x} p_{x t}+\theta_{y} p_{y t}+\theta_{z} p_{z t}+u_{p t}
$$

in which $p_{t}$ is the logarithm of the domestic price index at time $t$, and $\theta_{i}$ is the weight given to goods $i$ in the index with $\theta_{i}>0$ for $i=x, y, z$, and $\theta_{x}+\theta_{y}+\theta_{z}=1$. The error term, $u_{p t}$, captures the third country effect, and is assumed to be uncorrelated with $p_{i t}$, for $i=x, y, z$. We se this definition to eliminate $p_{z t}$ in equation (2):

$$
p_{t}=\left(\theta_{x}+\theta_{z}\right) p_{x t}+\theta_{y} p_{y t}+\alpha_{x} \theta_{z} x_{t}-\alpha_{z} \theta_{z} z_{t}-v_{z t}
$$

in which $v_{z t} \equiv \theta_{z} u_{z t}-u_{p t}$. The foreign country's counterpart of equation $(3)$ is

$$
\hat{p}_{t}=\left(\hat{\theta}_{x}+\hat{\theta}_{z}\right) \hat{p}_{x t}+\hat{\theta}_{y} \hat{p}_{y t}+\hat{\alpha}_{x} \hat{\theta}_{z} \hat{x}_{t}-\hat{\alpha}_{z} \hat{\theta}_{z} \hat{z}_{t}-\hat{v}_{z t}
$$

in which $\hat{v}_{z t} \equiv \hat{\theta}_{z} \hat{u}_{z t}-\hat{u}_{p t}$. Here and from now on, all variables and parameters pertaining to foreign country are designated by a hat.

For our purpose, the real exchange rate at time $t, q_{t}$, is defined as

$$
q_{t}=p_{t}-s_{t}-\hat{p}_{t}
$$

in which $s_{t}$ is the logarithm of nominal bilateral exchange rate. A decrease in $s_{t}$ means an appreciation of domestic currency. The purchasing power parity (PPP) doctrine states that nominal exchange rate equals the ratio between domestic and foreign prices. Therefore real exchange rate movements indicate deviations from the PPP for $p_{t}$. To sharpen our focus on the role of non-traded goods, we assume that the law of one price holds for the goods that are traded between the two countries. ${ }^{4}$ This is captured by the following relationship:

$$
p_{i t}=s_{t}+\hat{p}_{i t}
$$

for $i=x, y$. The assumption of the law of one price may not be as restrictive as it appears, we can easily abandon this assumption by allowing movements in $p_{i t}-s_{t}-\hat{p}_{i t}$. If these deviations contain a trend component, that is,

\footnotetext{
4 The law of one price obtains if 1) markets are competitive, 2) there are no transportation costs, and 3) there are no barriers to trade, such as tariffs or quotas. Hsieh (1982), Fisher and Park (1991) and Strauss (1996) among others also adopted this assumption for the traded goods.
} 
the PPP for $p_{x t}$ or $p_{y t}$ does not hold in the long run, $v_{z t}$ in equation (3) will contain trend component. Hence, checking if estimated residuals in equation (3) is stationary provides a diagnostic analysis for possible misspecification errors.

Substituting equation (3) and its foreign country's counterpart into equation (4) for $p_{t}$ and $\hat{p}_{t}$, respectively yields

$$
q_{t}=\left(\hat{\theta}_{y}-\theta_{y}\right)\left(p_{x t}-p_{y t}\right)+\alpha_{x} \theta_{z} x_{t}-\hat{\alpha}_{x} \hat{\theta}_{z} \hat{x}_{t}-\alpha_{z} \theta_{z} z_{t}+\hat{\alpha}_{z} \hat{\theta}_{z} \hat{z}_{t}+v_{t},
$$

in which $v_{t} \equiv-v_{z t}+\hat{v}_{z t}$. It is clear from equation (5) that trade between two countries imposes an equilibrium relationship among real exchange rate, terms of trade, and private consumption of various goods in the two countries. If $v_{t}$ is stationary, equation (5) imposes the restriction regulating the comovement of $q_{t}, p_{x t}-p_{y t}, x_{t}, \hat{x}_{t}, z_{t}$ and $\hat{z}_{t}$ from the consumer's perspective that

$$
q_{t}-\left(\theta_{y}-\hat{\theta}_{y}\right)\left(p_{x t}-p_{y t}\right)-\alpha_{x} \theta_{z} x_{t}+\hat{\alpha}_{x} \hat{\theta}_{z} \hat{x}_{t}+\alpha_{z} \theta_{z} z_{t}-\hat{\alpha}_{z} \hat{\theta}_{z} \hat{z}_{t}
$$

is stationary. We call this restriction the stationarity restriction, which is the foundation of cointegration-Euler equation approach. The derivation of this restriction does not require any use of budget constraint and first-order conditions relating to the intertemporal choice of consumption. Hence the cointegration-Euler equation approach allows for the existence of liquidity constraints or other financial market imperfections.

The stationarity restriction has different long run implications for the comovement of individual variables in equation (5), depending upon the trend properties of individual variables. For example, if the PPP for $p_{t}$ holds in the long run (that is, $q_{t}$ is stationary), then the stationarity restriction requires that $p_{x t}-p_{y t}, x_{t}, \hat{x}_{t}, z_{t}$ and $\hat{z}_{t}$ be cointegrated with the cointegrating vector: $\left(\hat{\theta}_{y}-\theta_{y}, \Pi^{\prime}\right)^{\prime}$, in which $\Pi^{\prime}=\left(\alpha_{x} \theta_{z},-\hat{\alpha}_{x} \hat{\theta}_{z},-\alpha_{z} \theta_{z}, \hat{\alpha}_{z} \hat{\theta}_{z}\right){ }^{5}$ Suppose there is a change in nominal exchange rate caused by nominal factors. Both traded and non-traded goods consumption in the two countries have a deterministic influence on the general price index in each country. As a result, changes in consumption of various goods in both countries have to manage to maintain the long run relationship between price ratios in the

\footnotetext{
5 Here we adopt the definition of cointegration given in Campbell and Perron (1991, p 164). An $n \times 1$ vector of variables, $S_{t}$, is said to be cointegrated if there exists at least one non-zero n-element vector $\beta$ such that $\beta^{\prime} S_{t}$ is trend stationary. This definition does not require that each of individual series in $S_{t}$ contain a unit root; some or all series can be trend stationary.
} 
two countries and nominal exchange rate, and the nominal factors have effects only on the short run movements of consumption. On the other hand, if $q_{t}$ contains a trend component and $p_{x t}-p_{y t}, x_{t}, \hat{x}_{t}, z_{t}$ and $\hat{z}_{t}$ are cointegrated with the cointegrating vector: $\left(\hat{\theta}_{y}-\theta_{y}, \Pi^{\prime}\right)^{\prime}$, then the stationarity restriction implies that private consumption in equation (5) cannot be a driving force for the long-run movement of $q_{t}$.

As argued in Hsieh (1982), different weights $\left(\theta_{i}\right)$ used in the construction of the price index can cause the movement of $q_{t}$. To see it, assume that the law of one price holds for both goods $X$ and goods $Y$ and that there is no non-traded goods in the world economy $\left(\theta_{z}=\hat{\theta}_{z}=0\right)$. Then equation (5) becomes

$$
q_{t}=\left(\hat{\theta}_{y}-\theta_{y}\right)\left(p_{x t}-p_{y t}\right)+v_{t}
$$

Clearly, it is the private consumption of non-traded goods that creates a link between real exchange rate and private consumption in the model. On the other hand, trade between the two countries links terms of trade changes with the real exchange rate changes. When $\hat{\theta}_{y} \neq \theta_{y}$ and $v_{t}=0$, terms of trade and real exchange rate have similar dynamics. It is the preference shocks that make real exchange rate and terms of trade have imperfect correlation. If there is only one goods, say goods $Y$, in the world economy, then $\theta_{y}=\hat{\theta}_{y}=1$ and equation (5) becomes $q_{t}=v_{t}$. That is, unlike the result obtained in Backus and Smith (1993), the PPP for $p_{t}$ does not necessarily hold exactly due to the presence of preference shocks.

Even though terms of trade can account for a significant fraction of real exchange rate movements here, the real exchange rate $\left(q_{t}\right)$ does not necessarily have positive correlation with the terms of trade. The sign of correlation is determined by that of $\hat{\theta}_{y}-\theta_{y}$. To see this, consider an increase in terms of trade $\left(p_{x t}-p_{y t}\right)$ caused by a lower price of importables. If consumption of importable goods is more important in home country than in foreign country in the sense that $\theta_{y}>\hat{\theta}_{y}$, then the value of a unit of domestic currency (in terms of a basket of goods) must rise relative to that of the equivalent units of foreign currency. When real exchange rate appreciates, it is optimal for private agents to increase the consumption of importables. For this case, terms of trade and real exchange rate are negatively correlated over time.

To identify other sources for the movement of $q_{t}$, assume that households in the two countries have identical preferences $\left(\alpha_{i}=\hat{\alpha}_{i}\right.$, for $\left.i=x, y, z\right)$ and that the weights used in the construction of price index are the same for 
the two countries. Given those assumptions, equation (5) can be reduced to

$$
q_{t}=\alpha_{x} \theta_{z}\left(x_{t}-\hat{x}_{t}\right)-\alpha_{z} \theta_{z}\left(z_{t}-\hat{z}_{t}\right)+v_{t}
$$

It is obvious that the cross-country consumption disparities for the traded and non-traded goods account for the movement of $q_{t}: q_{t}$ increases with the cross-country consumption disparity in traded goods but decreases with the cross-country consumption disparity in non-traded goods. A country that experienced a real appreciation of its currency had enjoyed either a more rapid growth in private consumption of traded goods or a less rapid growth in that of non-traded goods. Since non-traded goods will be relatively more expensive in the fast growing economies, the currency of these countries will experience a real appreciation.

Clearly, without preference shocks and the third country effect in the demand side, we cannot derive the long-run restriction on equilibrium relationship among real exchange rate, terms of trade and private consumption. For the productivity differential models (for example, Balassa (1964), Hsieh (1982) and Sameulson (1964)), productivity shocks did not play such a role. For example, in Hsieh's (1982) model, the supply of labor is fixed but is mobile between the tradable goods, and labor is the only input factor in production. Then the real exchange rate is a deterministic function of the following variables: productivity differentials between the tradable and non-tradable sectors in both countries and cross-country disparity in the unit labor costs of the traded goods.

\section{Econometric Specifications}

The stationarity restriction summarizes the long run equilibrium restrictions from the consumer's perspective. In the closed exchange economy, equilibrium consumption equals its production, and preference parameters can be identified from the stationarity restriction if the supply side exhibits much more volatility in the long run than the demand side. For example, Ogaki (1992) and Ogaki and Park (1989) achieved the identification by assuming that productivity shocks have stochastic trends.

Instead of modeling the production technology in the supply side, we consider open exchange economies in the world markets. Trading opportunities imply that the consumption of goods $X$ and $Y$ in each country may not equal domestic production in equilibrium. For highly open economies such as South Korea and Taiwan, the trend properties of equilibrium consumption of both exportable goods and importable goods are unlikely to be 
closely related to their domestic production. To achieve the identification of preference parameters, it is not sufficient to assume that the productivity shocks have stochastic trend. This can be done if the trend properties of export and import activities do not offset those of the corresponding production. And productivity shock is the dominant driving force in the long run.

In empirical investigation, it is difficult to obtain the data on the consumption of exportables and importables for the countries under study. The focus will be on the two goods case: traded goods and non-traded goods. Let $X_{t}$ denote the traded goods. Since $p_{x t}=p_{y t}$ in the two goods case, equation (5) can be reduced to

$$
q_{t}=\alpha_{x} \theta_{z} x_{t}-\hat{\alpha}_{x} \hat{\theta}_{z} \hat{x}_{t}-\alpha_{z} \theta_{z} z_{t}+\hat{\alpha}_{z} \hat{\theta}_{z} \hat{z}_{t}+v_{t}
$$

Equation (6) will be used to determine if private consumption of various goods are capable of placing restrictions on the long-run movement of real exchange rate in the two countries. According to the Campbell and Perron's (1991) definition of cointegration, even though the stationarity restriction implies that $q_{t}, x_{t}, \hat{x}_{t}, z_{t}$ and $\hat{z}_{t}$ are cointegrated, not all the individual series are required to contain a unit root. The stationarity restriction simply states that there exists at least a $5 \times 1$ vector: $\left(1,-\Pi^{\prime}\right)$ for $q_{t}, x_{t}, \hat{x}_{t}, z_{t}$ and $\hat{z}_{t}$ such that $v_{t}$ in equation (6) is trend stationary. Allowing the presence of trend stationary variables in equation (6) has important implications. If some of individual variables are trend stationary, it is trivially cointegrated. For example, if $q_{t}$ is trend stationary, then one trivial cointegrating vector is unit vector which selects the trend-stationary variable. When the model is true, another cointegrating vector is $\left(1, \Pi^{\prime}\right)^{\prime}$ with $\alpha_{x} \theta_{z} x_{t}-\hat{\alpha}_{x} \hat{\theta}_{z} \hat{x}_{t}-\alpha_{z} \theta_{z} z_{t}+$ $\hat{\alpha}_{z} \hat{\theta}_{z} \hat{z}_{t}$ being trend stationary. That is, even private consumption contains trend components, the stationarity restriction does not necessarily imply that private consumption is a driving force for the long-run movement of real exchange rate.

To assess the empirical significance of heterogeneous utility function across countries, we follow the tradition in international trade and assume $\alpha_{i}=\hat{\alpha}_{i}$ for $i=x, z$ and $\theta_{z}=\hat{\theta}_{z}$. Then equation (6) can be further simplified to

$$
q_{t}=\alpha_{x} \theta_{z}\left(x_{t}-\hat{x}_{t}\right)-\alpha_{z} \theta_{z}\left(z_{t}-\hat{z}_{t}\right)+v_{t}
$$

If real exchange rate and the cross-country consumption disparity, $x_{t}$ $\hat{x}_{t}$ and $z_{t}-\hat{z}_{t}$ contain different trend components, then the stationarity restriction implies that $q_{t}, x_{t}-\hat{x}_{t}$ and $z_{t}-\hat{z}_{t}$ are cointegrated. However, 
when $q_{t}$ is stationary, the stationarity restriction does not necessarily imply the stationarity of $y_{t}-\hat{y}_{t}$ and $z_{t}-\hat{z}_{t}$ for the following reason. $y_{t}-\hat{y}_{t}$ and $z_{t}-\hat{z}_{t}$ can be cointegrated with the cointegrating vector: $\left(\alpha_{x} \theta_{z},-\alpha_{z} \theta_{z}\right)$ so that $\alpha_{x} \theta_{z}\left(x_{t}-\hat{x}_{t}\right)-\alpha_{z} \theta_{z}\left(z_{t}-\hat{z}_{t}\right)$ is stationary. For this case, if goods $X$ has a lower income elasticity than goods $Z\left(\alpha_{x}>\alpha_{z}\right)$, then the stationarity of $q_{t}$ forces $z_{t}-\hat{z}_{t}$ to grow at a faster rate than $x_{t}-\hat{x}_{t}$, but private consumption do not have long run effects on $q_{t}$. In general, the cointegration between $x_{t}-\hat{x}_{t}$ and $z_{t}-\hat{z}_{t}$ does not imply the stationarity of $\alpha_{x} \theta_{z}\left(x_{t}-\hat{x}_{t}\right)-$ $\alpha_{z} \theta_{z}\left(z_{t}-\hat{z}_{t}\right)$, the absence of arbitrage opportunities in the non-traded goods between the two countries is very likely to induce the non-stationarity of $q_{t}$. Finally, the estimates of $\alpha_{x} / \alpha_{z}$ and $\hat{\alpha}_{x} / \hat{\alpha}_{z}$ can be identified in the above two specifications.

\section{Data and Empirical Results}

As displayed in Figures 1 and 2, consumption of both traded and nontraded goods and bilateral real exchange rate all exhibit clear trends. The focus here is to explore the stationarity restriction under the assumption that these series contain trend components. We first present statistical tests for the trend property of individual series, and then estimate various cointegrating regressions under the two specifications of preference parameters and the weights given in the construction of $p_{t}$.

Data

The countries involved are Japan, South Korea, Taiwan and the U.S. Two sets of bilateral relations are examined with South Korea and Taiwan each serving as the home country. Data on the exchange rate of New Taiwan dollars against U.S. dollar and Japanese Yen were taken from Taiwan Monthly Financial Statistics, while the exchange rates of Korean Won against the two foreign currencies were taken from International Financial Statistics (IFS). To study the sensitivity of empirical results with respect to the use of price index as the measure of general price level, the two selections of $p_{t}$ are: CPI and WPI (or PPI). Japan and South Korea price series were taken from IFS. Taiwan price series were taken from Taiwan Natioanl Income Accounts, while U.S. series were taken from Bureau of Labor Statistics. Let $q_{t}^{c}$ denote the real exchange rate when CPI is the measure of price index, and let $q_{t}^{w}$ denote the real exchange rate when WPI is the measure.

Following Kakkar and Ogaki (1993), the real consumption expenditure on durable, semi-durables and non-durables is defined as the consumption 
of traded goods, while the real consumption expenditure on services is defined as the consumption of non-traded goods. South Korea data on $x_{t}$ and $z_{t}$ were taken from National Accounts, published by Bank of Korea, while Taiwan series were taken from the Taiwan Natioanl Income Accounts. The Japan series on $\hat{x}_{t}$ and $\hat{z}_{t}$ were taken from OECD Quarterly National Accounts, and U.S. series were taken from Survey of Current Business, published by Department of Commerce. The per capita real consumption on goods and services is constructed as follows. We deflate nominal consumption expenditure by appropriate price index, and then divide the resulting number by total population. All data are quarterly series. The sample period is 1975:1-1994:4 for Taiwan and U.S., and 1975:1-1993:4 for Japan and South Korea.

\section{Evidence from time series data}

The real bilateral exchange rates are displayed in Figure 1, the plots of $x_{t}, z_{t}, \hat{x}_{t}$ and $\hat{z}_{t}$ in Figure 2, and those of $x_{t}-\hat{x}_{t}$ and $z_{t}-\hat{z}_{t}$ in Figure 3. Three points worth mentioning. First, Taiwan generally experienced a real appreciation of its currency against U.S. dollars during the sample period. The nominal depreciation of New Taiwan dollars against the U.S. dollars caused a real depreciation of Taiwan's currency from 1981 to 1986, and then the real value of New Taiwan dollars was pushed up under the pressure of the U.S. when Taiwan enjoyed a sizable current account surplus in the 1986-1989 period. On the other hand, the bilateral exchange rate of Korean Won against the U.S. dollars exhibits a less clear upward trend. The real depreciation of Korean Won in 1980 and in the 1982-1986 was caused by the continuing nominal depreciation of Korean Won against U.S. dollars. When South Korea began to enjoy sizable current account surplus in 1986, Korean Won was under pressure by the U.S. to have an unprecedented appreciation against the U.S. dollars through 1989. After 1989, mild real depreciation of the Won against the U.S. dollars were mainly due to two factors: the deterioration of South Korean international payment position and the appreciation of Japanese Yen against the U.S. dollars since 1991. As a result, the real value of Korean won against U.S. dollars fell to the level of the late 1970s in 1993-1994. The bilateral real exchange rate between South Korea and Japan exhibited a similar and clear upward trend in the 1975-1994 period. Unlike the real exchange rate in South Korea, the real exchange rate between Taiwan and Japan exhibits a downward trend with volatile fluctuations. 
Second, the real per capita private consumption expenditures on traded goods and non-traded goods contain different trend components in the four countries. Third and finally, the cross-country evidence in Figure 2 indicates that the per capita real consumption of services increases with economic development. This evidence is also shown in the cross-country disparities in the private consumption on traded goods and non-traded goods in four pairs of countries.

\section{Testing for the PPP doctrine}

We first test the trend property of bilateral real exchange rate between home country and foreign country. If the real exchange rate does not contain a trend component, then the PPP doctrine for $p_{t}$ holds in the long run. Otherwise, it does not hold in the long run. Therefore, testing the trend property of bilateral exchange rate is equivalent to testing the PPP doctrine. For this purpose, we use Park and Choi's (1988) $J(p, q)$ and $G(p, q)$ tests. The null of difference stationary around the linear time trend is rejected when the $J(1 ; q)$ statistic is smaller than the critical values tabulated in Park and Choi (1988). ${ }^{6}$ We also report Park and Choi's (1988) $G(1, q)$ test for the stationarity of those series around the linear time trend (trend stationarity). According to Park and Choi $(1988), G(1, q)$ converges in distribution to a $\chi^{2}(q-1)$ random variable under the null of trend stationarity. We reject the null when $G(1, q)$ test statistic is larger than critical values. ${ }^{7}$ Table 1 displays test results for the trend property of bilateral real exchange rate.

For $q_{t}^{c}$ and $q_{t}^{w}$ between Taiwan and U.S., the $J(1, q)$ tests with $q=$ $2,3,4$ cannot reject the null of difference stationarity around the linear time trend at the $10 \%$ significance level. There is evidence against the null of the trend stationarity of $q_{t}^{c}$ at the $5 \%$ significance level in terms of $G(1,2)$ and $G(1,4)$ tests. On the other hand, the $G(1, q)$ tests with $q=2,3,4$ yield weaker evidence against the trend stationarity of $q_{t}^{w}$.

For $q_{t}^{c}$ between Taiwan and Japan, $J(1, q)$ tests all reject the null of difference stationary. The $J(1,3)$ and $J(1,4)$ tests even reject it at the

6 The $J(p, q)$ test does not require the estimation of the long-run variance and has an advantage over the Phillips and Perron's $Z_{\alpha}\left(Z_{t}\right)$ test and Augmented Dickey-Fuller (ADF) test in that neither the bandwidth parameter nor the order of autoregression needs to be chosen. The Monte Carlo experiments also show that the $J(p, q)$ test has a stable size and is not dominated by the ADF test in small samples in terms of powers.

7 Kahn and Ogaki (1992) recommend small $q$ when the sample size is small according to their Monte Carlo simulations. Here, we chose $q=2,3$ and 4. For estimation of the long-run variance, we use Andrews' (1991) quadratic spectral kernel with the automatic bandwidth parameter estimator based on $\mathrm{AR}(1)$. 
$1 \%$ significance level. When WPI is the measure of $p_{t}$, there is slightly improved evidence for the null of difference stationarity for $q_{t}^{w}$. The $J(1,3)$ and $J(1,4)$ tests still reject the null, and only $J(1,2)$ fails to reject it at the $10 \%$ significance level. On the other hand, we did not find significant evidence against the null of trend stationarity for both $q_{t}^{c}$ and $q_{t}^{w}$ in terms of the $G(1, q)$ tests. $^{8}$

There is conflicting evidence for the trend property of $q_{t}^{c}$ between South Korea and Japan. We found that the $J(1,2)$ and $J(1,4)$ tests cannot reject the null of difference stationarity. But results of the $G(1, q)$ tests with $q=2,3,4$ also support the null of trend stationarity. On the other hand, there is more consistent evidence for the difference stationarity of $q_{t}^{w}$. The $J(1, q)$ tests with $q=2,3,4$ all fail to reject the null of difference stationarity of $q_{t}^{w}$ at the $10 \%$ significance level. Only the $G(1,3)$ test fails to reject the null of trend stationarity for $q_{t}^{w}$ at the $10 \%$ significance level. Finally, for $q_{t}^{c}$ between South Korea and U.S., both $J(1, q)$ and $G(1, q)$ tests with $q=$ $2,3,4$ provided significant evidence for the null of difference stationarity. However, there is slightly weaker evidence for the difference stationarity of $q_{t}^{w}$ in terms of the $J(1, q)$ tests. Only the $G(1,2)$ and $G(1,3)$ tests fail to reject the null of trend stationarity.

Our empirical findings can be summarized as follows. First, the bilateral exchange rates contain a unit root and linear time trend in South Korea/Japan, South Korea/U.S. and Taiwan/U.S. cases. And $q_{t}^{c}$ and $q_{t}^{w}$ between Taiwan and Japan are stationary around a linear time trend. These results are generally consistent with the findings in Corbae and Ouliaris (1988) and Fisher and Park (1991) using the data in other countries. They test the stationarity of real exchange rate based upon the null hypothesis that nominal exchange rate and price are cointegrated with the normalized cointegrating vector implied by equation (4), and found evidence against the stationarity of real exchange rate. Second, the measure of $p_{t}$ chosen in testing the trend property of real exchange rate does not matter for the long-run deviation of PPP for $p_{t}$. Recently, based upon the data in other countries, Kim (1990) and Kakkar and Ogaki (1993) found more favorable evidence for the long-run PPP when WPI is used as the measure of $p_{t}$ than when CPI is used. They argued that a large weight given to the non-traded

8 We report the ADF test in Table 3 because it was widely used in the literature. None of the $A D F$ tests reject the null of difference stationary for both $q_{t}^{c}$ and $q_{t}^{w}$ in the Taiwan/Japan and Taiwan/U.S. cases. In the following discussion, we only present the $J(p, q)$ and $G(p, q)$ test results when there is no conflicting evidence between these tests and the ADF test. 
goods in CPI could be the reason that the long-run PPP doctrine based upon CPI did not receive much empirical support.

\section{Testing for the trend property of private consumption}

Given the trend property of real exchange rate presented above, private consumptions in different countries are required to exhibit trends in order to account for the long-run movement of real exchange rate under the stationarity restriction. Table 2 presents test results for the trend property of $x_{t}$, $z_{t}, \hat{x}_{t}$ and $\hat{z}_{t}$. Here $x_{t}$ and $z_{t}$ are the home country's real private consumption expenditures on goods (durables, semi-durables and non-durables) and services, respectively, while $\hat{x}_{t}$ and $\hat{z}_{t}$ are the foreign country's counterparts of $x_{t}$ and $z_{t}$, respectively.

First, for both $x_{t}$ and $z_{t}$ in Taiwan, the null of difference stationary around the linear time trend cannot be rejected at the $10 \%$ significance level in terms of $J(1, q)$ tests with $q=2,3,4$, and the $G(1, q)$ tests with $q=2,3,4$ all significantly reject the null of trend stationarity in favor of the difference stationarity at the $1 \%$ significance level. Second, the null of difference stationarity for both $x_{t}$ and $z_{t}$ in South Korea received strong supports from the $J(1, q)$ tests, and the $G(1, q)$ tests also yield significant evidence against the null of the trend stationarity for these two series. In the light of the above results, we assume that both $x_{t}$ and $z_{t}$ in South Korea and Taiwan contain a unit root and linear time trend.

For the U.S. series of $\hat{x}_{t}$, we found weaker evidence for the null of difference stationary around the linear trend. Even though the null of trend stationarity is rejected at the $10 \%$ significance level in terms of the $G(1, q)$ tests with $q=2,3,4$, both $J(1,2)$ and $J(1,4)$ tests reject the null of difference stationarity at the $10 \%$ significance level. On the other hand, there is significant evidence for the null of difference stationarity for the U.S. series of $\hat{z}_{t}$. These results are also confirmed by results of the $G(1, q)$ tests. For $\hat{x}_{t}$ and $\hat{z}_{t}$ in Japan, there is mixed evidence for the difference stationarity. First, both $J(1,2)$ and $J(1,3)$ tests reject the null of difference stationarity for $\hat{x}_{t}$ at the $10 \%$ significance level. Second, the $J(1, q)$ tests with $q=2,3,4$ cannot reject the null of difference stationarity of $\hat{z}_{t}$ at the $10 \%$ significance level. They are consistent with results of the $G(1, q)$ tests in Table 2. Based upon the test results on the trend property of $\hat{z}_{t}$, we assume that $\hat{z}_{t}$ in Japan and U.S. contains a unit root and linear time trend. Since the $G(p, q)$ test tends to over-reject the null when the autoregressive root is close to one, the above findings can be viewed as conclusive evidence for the trend stationarity of $\hat{x}_{t}$ in Japan and U.S. 
Recently, Ogaki and Park (1989) found significant evidence for the null of the difference stationarity for the U.S. data on $\hat{z}_{t}$ in terms of both $J(1, q)$ test and the Phillips and Perron's $Z_{\alpha}\left(Z_{t}\right)$ test, and evidence against the trend stationarity of $\hat{z}_{t}$ in terms $G(1, q)$ tests at the $5 \%$ significance level. They used seasonally adjusted monthly data on durables, non-durables and services in National Income and Product Accounts (NIPA). The sample period is from January 1959 to December 1986. When the shorter sample period is used (February 1968 - December 1986), the null of the trend stationarity for $\hat{z}_{t}$ cannot be rejected. Given the mixed evidence on the null of difference stationarity for the consumption on durables and nondurables, their findings are generally consistent our results.

Testing for cross-country consumption disparity

If preference parameters and weights used in the construction of $p_{t}$ are identical across home country and foreign country, the cross-country consumption disparity must be nonstationary to account for the long-run movement of real exchange rate. For this purpose, we conduct the test for the cointegration between private consumption in different countries. If domestic consumption and foreign consumption on traded goods (nontraded goods) are not cointegrated with the normalized cointegrating vector: $(1,-1)$, then the cross-country consumption disparity for traded goods (non-traded goods) contains a trend component.

Here we use the Park's (1992) $H(p, q)$ statistics in testing the cointegrating relationship. Park (1992) showed that the $H(p, q)$ statistic converges in distribution to a $\chi^{2}(p-q)$ random variable under the null of cointegration. In particular, the $H(0,1)$ statistic can be used to test the deterministic cointegrating restriction. According to the $H(p, q)$ statistics in Table 3, we found much evidence against the cointegration between $x_{t}$ and $\hat{x}_{t}$ (and between $z_{t}$ and $\hat{z}_{t}$ ) for all possible pairs of home and foreign countries: the deterministic cointegration restriction was rejected by the $H(0,1)$ test, while the stochastic cointegration restriction was rejected by the $H(1, q)$ tests with $q=2,3,4$ at the $1 \%$ significance level. These results are consistent with visual impressions obtained in Figure 4. Both test results and visual impressions all clearly indicated the cross-country consumption disparity for traded and non-traded goods contains a trend component.

One possibility for the cross-country consumption disparity is that the intertemporal elasticity of substitution rises as an economy is richer. There are two approaches to generate the time-varying intertemporal elasticity of 
substitution. First, the time-varying rate of time preference $\left(\theta_{t}\right)$ falls as an economy is richer. Facing the same real interest rate in the world credit market, agents with lower rate of time preference have more incentives to postpone their current consumption for future consumption. Hence, lower time preference rate induces higher consumption growth rate. Second, there is subsistence level in consumption. When the level of consumption is near the subsistence level, agent's major concern is meeting the subsistence requirement. The marginal utility of consumption shoots off to infinity, which discourages saving. When an economy begins to grow, agents become more willing to substitute current consumption for future consumption so that the subsistence requirement induces an increasing intertemporal elasticity of substitution. For example, Lin (1996) emphasized the importance of the subsistence level of consumption, and found that Japan, South Korea and Taiwan data provided evidence for this implication for the intertemporal elasticity of substitution. ${ }^{9}$

\section{Testing for stationarity restriction}

Given the difference stationarity of $q_{t}$, the stationarity restriction in equation (6) simply implies that private consumption in different countries is not cointegrated with the cointegrating vector: $\Pi^{\prime}$ and they are the driving force for the long run movement of $q_{t}$. It is possible that private consumption in different countries is cointegrated with other cointegrating vectors. The hypothesis testing strategy here is that we conduct the cointegration tests for private consumption in different countries with and without the real exchange rate included. If the test results fail to reject the null of cointegration for the set of variables excluding $q_{t}$, but reject the null for the set of variables including $q_{t}$, then the long run movements of $q_{t}$ cannot be driven by private consumption in different countries.

Table 3 reports the $H(0, q)$ and $H(1, q)$ tests for the null of cointegration for the four private consumption series. When Taiwan (U.S.) is designated as the home (foreign) country, the $H(0,1)$ test fails to reject the null of deterministic cointegration for $x_{t}, \hat{x}_{t}, z_{t}$ and $\hat{z}_{t}$, and the $H(1, q)$ tests with $q=2,3,4$ also provide strong evidence for the null of stochastic cointegration restriction. When Japan is the foreign country, the $H(0,1)$ test rejects the null of the deterministic cointegration for $x_{t}, \hat{x}_{t}, z_{t}$ and $\hat{z}_{t}$

${ }^{9}$ Using the Indian villages' panel data, Atkeson and Ogaki (1991) found that the rate of time preference is constant across poor and rich households, while the intertemporal elasticity of substitution is higher for rich households than it is for poor households. However, as shown in Lin (1996), the subsistence requirement will drastically change the estimation procedure. 
at the $10 \%$ significance level. However, the $H(1, q)$ tests with $q=2,3,4$, strongly favor the stochastic cointegration restriction.

We found much evidence against the null of cointegration $x_{t}, \hat{x}_{t}, z_{t}$ and $\hat{z}_{t}$ in the South Korea/Japan and South Korea/U.S. cases. Only the deterministic cointegration restriction in the South Korea/Japan case cannot be rejected by the $H(0,1)$ test. There are more than a single source of non-stationarity in generating the long-run movements of $x_{t}, \hat{x}_{t}, z_{t}$ and $\hat{z}_{t}$ here.

Next, we apply the $H(p, q)$ tests to $q_{t}, x_{t}, \hat{x}_{t}, z_{t}$ and $\hat{z}_{t}$, and the results are given in Table 3 . Using both measures of $p_{t}$, we found little evidence against the stationary restrictions in the Taiwan/Japan and Taiwan/U.S. cases: neither the deterministic cointegration restriction was rejected by the $H(0,1)$ test, nor the stochastic cointegration restriction was rejected by the $H(1, q)$ tests with $q=2,3,4$. Despite private consumption series are cointegrated in these two cases, the above finding clearly suggests that the private consumption in different countries can account for the longrun movements of real exchange rate and the private consumption series are cointegrated with the cointegrating vector other than $\Pi^{\prime}$. In previous subsections, we found evidence for the trend stationarity of $q_{t}$ between Taiwan and Japan and $\hat{x}_{t}$ in Japan and U.S. These results apparently did not affect the test results for the stationarity restriction.

There is mixed evidence for the stationarity restriction in the South Korea/Japan case in terms of $H(p, q)$ tests in Table 3 . When CPI is the measure of $p_{t}$, the $H(0,1)$ test fails to reject the deterministic cointegration for $q_{t}, x_{t}, \hat{x}_{t}, z_{t}$ and $\hat{z}_{t}$. On the other hand, the stochastic cointegration restriction was rejected by the $H(1,2)$ test at the $10 \%$ significance level. When WPI is the measure of $p_{t}$, the stationarity restriction was rejected by the $H(0,1)$ test but cannot be rejected by $H(1, q)$ tests with $q=2,3,4$. For the South Korea/U.S. case, we found little evidence against the stationarity restriction: neither the $H(0,1)$ test nor the $H(1, q)$ tests with $q=2,3,4$ reject the null of cointegration at the $10 \%$ significance level. Even though cointegration exists for the four consumption series, the difference stationarity of $q_{t}$ and the stationarity restriction together imply that private consumption accounts for the long run movement of real exchange rate.

When we assume that preference parameters and weights used in the construction of $p_{t}$ are identical across home country and foreign country, the stationarity restriction in equation (7) implies that the cross-country consumption disparity account for the long-run movement of real exchange 
rate. Next we present the $H(p, q)$ test results in Table 3. First, we found significant evidence for the stationarity restriction in the Taiwan/Japan case, and weaker evidence for the stationarity restriction in the Taiwan/U.S. case: the deterministic cointegration restriction was rejected by the $H(0,1)$ test, but the stochastic cointegration restriction cannot be rejected by the $H(1, q)$ tests with $q=2,3,4$. Second, the stochastic cointegration restriction cannot be rejected by the $H(1, q)$ tests with $q=2,3,4$ in the South Korea/Japan and South Korea/U.S. cases.

\section{Cointegrating regression results}

In addition to stationarity restriction, the model imposes restrictions on the sign of coefficients in the cointegrating regressions. Even though the cointegrating relationship exists between real exchange rate and private consumption in different countries, it is necessary to investigate the sign of coefficient estimates as an evaluation of the performance of the model. Table 4 reports the cointegrating regression results using Park's (1992) CCR procedure, and Phillips and Hansen's (1990) FM procedure. As noted by Ogaki and Park (1989), one remarkable feature of cointegrating regressions is that structural parameters, $\alpha_{x} / \alpha_{z}$ and $\hat{\alpha}_{x} / \hat{\alpha}_{z}$, can be estimated consistently by these procedures without the assumption that regressors are econometrically exogenous.

When preference parameters and weights used in the construction of $p_{t}$ are identical across home country and foreign country, those countries which experienced an appreciation in real exchange rate have enjoyed either relatively more rapid growth in private consumption of traded goods or relatively less rapid growth in private consumption of nontraded goods. For the South Korea/Japan and South Korea/U.S. cases, the cointegrating regression results in Table 4 clearly indicate that estimates of $\alpha_{x} \theta_{z}$ and $\alpha_{z} \theta_{z}$ have the theoretically correct signs. South Korea experienced mild real appreciations against both U.S. dollor and Japanese Yen during the sample period, and $x_{t}-\hat{x}_{t}$ and $z_{t}-\hat{z}_{t}$ exhibit clear upward trends in these two cases. Hence the mild real appreciation of Korean Won can be attributed to more rapid growth both in $x_{t}$ and in $z_{t}$ for South Korea. Note that $\alpha_{x} / \alpha_{z}$ measures the ratio of income elasticities of $z_{t}$ and $x_{t}$ in South Korea. The instability of the ratio across the two cases indicates that the model does not perform well in this aspect. On the other hand, we had the theoretically wrong signs for estimates of $\alpha_{x} \theta_{z}$ and $\alpha_{z} \theta_{z}$ in the Taiwan/Japan case. Unlike the other three real exchange rates in Figure 1, the bilateral

real exchange rate between Taiwan and Japan exhibits a downward trend, 
which reflects the depreciation of New Taiwan dollars against Japanese Yen. Facing the continuing real appreciation of Japanese Yen, private agents in Japan are expected to increase their consumption of traded goods by increasing the imports from Taiwan, and those in Taiwan are expected to substitute relatively cheaper non-traded goods for more expensive traded goods. However, Taiwan enjoyed relatively more rapid growth in both $x_{t}$ and $z_{t}$ as clearly displayed in Figure 3 . As a result, the sign of coefficient estimates for $x_{t}-\hat{x}_{t}$ and $z_{t}-\hat{z}_{t}$ must change to account for the declining pattern of bilateral real exchange rate. That is, the substitution effects cannot be a crucial element in the determination of real exchange rate. Finally, for the Taiwan/U.S. case, we found that the coefficient estimates of $\alpha_{z} \theta_{z}$ have wrong signs for the following reason. Since Taiwan experienced a real appreciation against U.S. dollars, the model predicts that private agents in Taiwan enjoy less rapid growth in the consumption of non-traded goods. As displayed in Figure 3, Taiwan had more rapid growth in $z_{t}$. It forces the sign of $\alpha_{z} \theta_{z}$ estimate to change.

We had consistent cointegrating regression results in equation (6). These results at least make two points clear. First, private consumption can account for the long run movement of real exchange rate. Second, if we take the restrictions on the signs of coefficients imposed by the model seriously, it is necessary to refine the specifications of the model so that private consumption can deliver the reliable effects on the real exchange rate.

\section{Private consumption vs. government consumption}

An alternative explanation of the long run movement of real exchange rate is that of government consumption expenditure recently proposed by Froot and Rogoff (1991). The channel linking between government consumption expenditure and real exchange rate can be described as follows. When a larger fraction of government consumption expenditure falls on the non-traded goods than does private consumption, an increase in government consumption increases the real appreciation of domestic currency against foreign currency. Therefore, those countries that experienced real appreciation against the foreign currency have enjoyed relatively more rapid growth in government consumption expenditure.

Table 5 shows the results of cointegrating regressions of the real exchange rate on private consumption and governement consumption expenditure:

$$
q_{t}=\alpha_{x} \theta_{z} x_{t}-\hat{\alpha}_{x} \hat{\theta}_{z} \hat{x}_{t}-\alpha_{z} \theta_{z} z_{t}+\hat{\alpha}_{z} \hat{\theta}_{z} \hat{z}_{t}+\gamma g_{t}-\hat{\gamma} \hat{g}_{t}+v_{t}^{\prime}
$$


in which $g_{t}$ and $\hat{g}_{t}$ are per capita real government consumption expenditure in the home country and foreign country, respectively. If government consumption expenditure is assumed to totally fall on the non-traded goods, then the movement of the private consumption of non-traded goods completely reflects that of government consumption spending. Hence, we expect that the coefficient estimates of $\gamma$ and $\hat{\gamma}$ are insignificant from zero once the private consumption of traded and non-traded goods is a regressor in the cointegrating regressions. In general, we expect that $\gamma>0$ and $\hat{\gamma}>0$. The evidence in Table 5 indicates that the empirical relationships between real exchange rate and private consumption are not significantly affected by the presence of government consumption expenditure in the cointegrating regressions. The data show no evidence of the government consumption effects on real exchange rates. Some of coefficients on government consumption in the home country and foreign country are not statistically different from zero and are even of the wrong signs. The inclusion of government consumption regressors in (8) has little effects on the estimates of $\alpha_{x} \theta_{x}$, $\hat{\alpha}_{x} \hat{\theta}_{z}, \alpha_{z} \theta_{z}$ and $\hat{\alpha}_{z} \hat{\alpha}_{z}$. This remains as statistically significant as before, with the signs for coefficient estimates unchanged.

To access the empirical significance of cross-country disparity in real government consumption, $g_{t}-\hat{g}_{t}$, in the cointegrating regression of (7), Table 5 also presents the results of the following cointegrating regression:

$$
q_{t}=\alpha_{x} \theta_{z}\left(x_{t}-\hat{x}_{t}\right)-\alpha_{z} \theta_{z}\left(z_{t}-\hat{z}_{t}\right)+\gamma\left(g_{t}-\hat{g}_{t}\right)+v_{t}^{\prime \prime}
$$

We have similar results for the cross-country disparity in government consumption effects on the real exchange rate as above. The coefficients on domestic and foreign private consumption become larger and even more statistically significant when $g_{t}-\hat{g}_{t}$ is included. But the wrong signs for the estimates of $x_{t}-\hat{x}_{t}$ and $z_{t}-\hat{z}_{t}$ remain quite severe. Thus, accounting for government consumption does not seem to overturn the result that private consumption affects. the long run movement of real exchange rate.

\section{Concluding Remarks}

The empirical evidence suggests that private consumption in the home and foreign countries provide a significant component of the explanation on the long run movement of real exchange rate in South Korea and Taiwan. Based upon the signs of coefficient estimates in the cointegrating regressions, it seems that the private consumption may not be a reliable fundamental that has reliable effects on the real exchange rate. 
It is useful to incorporate the supply-side elements such as the productivity differentials in a general equilibrium model of real exchange rate determination, and explore the trend and cyclical implications from equilibrium relationships obtained in the model. Since fluctuation in the relative price of traded goods accounts for a significant fraction of the real exchange rate movement, another interesting topic for future research is to estimate equation (5). 


\section{Reference}

Adler, Michael and B. Lehmann (1983). "Deviations from purchasing power parity in the long run." Journal of Finance 38: 1471-87.

Andrews, Donald W. K. (1991). "Heteroskedasticity and autocorrelation consistent covariance matrix estimation." Econometrica 59: 817-858.

Atkeson, Andrew and M. Ogaki (1991). "Wealth-varying intertemporal elasticity of substitution: Evidence from panel and aggregate data." Manuscript, Rochester, New York: University of Rochester.

Backus, David K. and G. W. Smith (1993). "Consumption and real exchange rates in dynamic economies with non-traded goods." Journal of International Economics 35: 297-316.

Backus, David K., P. J. Kehoe and F. E. Kydland (1992). "International real business cycles." Journal of Political Economy 100: 745-775.

Balassa, Bela (1964). "The Purchasing-power parity: A reappraisal." Journal of Political Economy 72: 584-596.

Campbell, J. Y. and P. Perron (1991). "Pitfalls and opportunities: What macroeconomists should know about unit roots." in Macroeconomics Annual, eds. by O. Blanchard and S. Fischer, Cambridge, Mass.: MIT Press, 141-201.

Corbae, Dean and S. Ouliaris (1988). "Cointegration and tests of purchasing power parity." Review of Economics and Statistics: 508-11.

Devereux, M. B., A. W. Gregory and G. W. Smith (1992). "Realistic cross-country consumption correlations in a two-country, equailibrium, business cycle model." Journal of International Money and Finance 11: 3-16.

Fisher, Eric O. and J. Y. Park (1991). "Testing purchasing power parity under the null hypothesis of co-integration." Economic Journal 101: 1476-1484.

Froot, K.A. and K. Rogoff (1991). "The EMS, the EMU, and the Transition to a Common Currency", in Macroeconomics Annual 1991, eds. by O. Blanchard and S. Fischer, Cambridge, MA: MIT Press, 269-371.

Hsieh, David A. (1982). "The determination of the real exchange rate: The productivity approach." Journal of International Economics 12: 355-362.

Huizinga, John (1987). "An empirical investigation of the long run behavior of real exchange rate," in Empirical Studies of Velocity, Real Exchange 
Rates, Unemployment and Productivity, eds. by Karl Brunner and Allan H. Meltzer, Carnegie-Rochester Conference Series on Public Policy, 27: 149-214.

Ito, Takatoshi, P. Isard and S. Symansky (1996). "Economic growth and real exchange rate: An overview of the Balassa-Samuelson Hypothesis in Aisa." Manuscript presented at the 7th Annual East Asian Seminar on Economics, Hong Kong.

Kahn James A. and M. Ogaki (1992). "A consistent test for the null of stationary against the alternative of a unit root." Economics Letters 39: 7-11.

Kakkar, Vikas and M. Ogaki (1993). "Real exchange rates and nontradables." Manuscript. Rochester, New York: University of Rechester.

Kim, Yoonbai (1990). "Purchasing power parity: Another look at the longrun data." Economics Letters 32: 339-44.

Kollman, Robert (1991). "Essays on international business cycles." Ph.D. thesis, University of Chicago.

Kravis, Irving B. and R. E. Lipsey (1987). "The assessment of national price levels." in Real and Financial Linkages among Open Economies, eds. by S.W. Arndt and J.D. Richardson, Cambridge, MA: MIT Press, 97-134.

Lin, Kenneth S. (1996). "Saving, wealth and the subsistence level of consumption." Manusacript. Taipei, Taiwan: National Taiwan University.

Lucas, Robert E. Jr. (1982). "Interest rates and currency prices in a twocountry world." Journal of Monetary Economics 10: 335-60.

Mark, Nelson C. (1990). "Real and nominal exchange rates in the long run: An empirical investigation." Journal of International Economics. 28: 115-136.

Ogaki, Masao (1992). "Engel's law and cointegration." Journal of Political Economy, 100: 1027-1046.

Ogaki, Masao and Y.Y. Park (1989). "A cointegration approach to estimating preference parameters." Manuscript, Rochester, New York: University of Rechester.

Park, Joon Y. (1992). "Canonical cointegrating regressions." Econometrica 60: $119-143$.

Park, Joon Y. and B. Choi (1988). "A new approach to testing for a unit root." Mimeo, Ithaca, N.Y.: Cornell University. 
Phillips, P. C. B. and B. E. Hansen (1990). "Statistical inference in instrumental variables regression with I(1) processes." Review of Economic Studies 57: 99-125.

Samuelson, Paul (1964). "Theoretical note on trade problems." Review of Economics and Statistics 46: 145-154.

Strauss, Jack (1996). "The cointegrating relationship between productivity, real exchange rates and purchasing power parity." Journal of Macroeconomics 18: 299-313.

Stulz, Rene M. (1987). "An equilibrium model of exchange rate determination and asset pricing with non-traded goods and imperfect information." Journal of Political Economy 95: 1024-1040.

- n96.tex (August 15, 1996) 

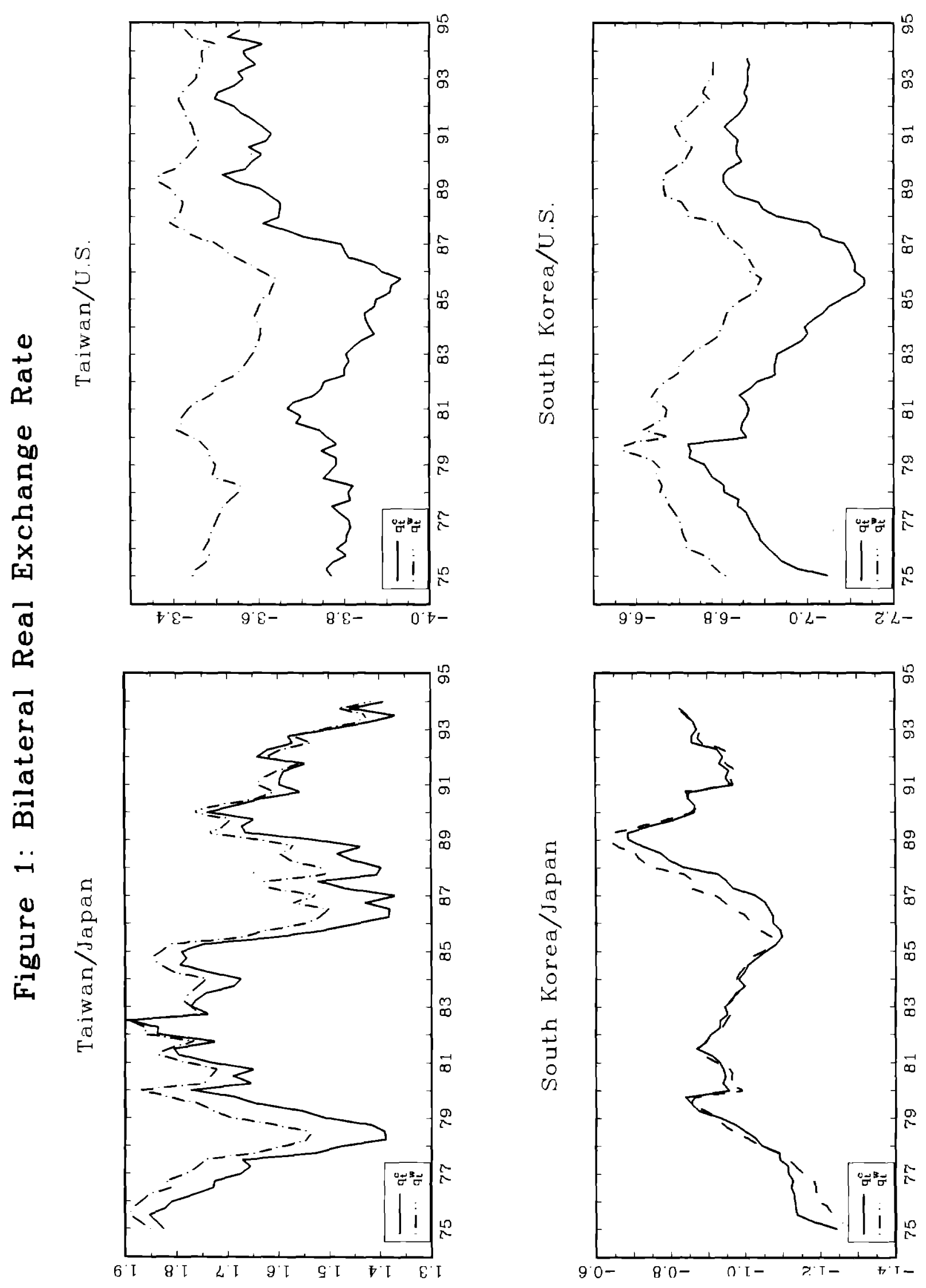

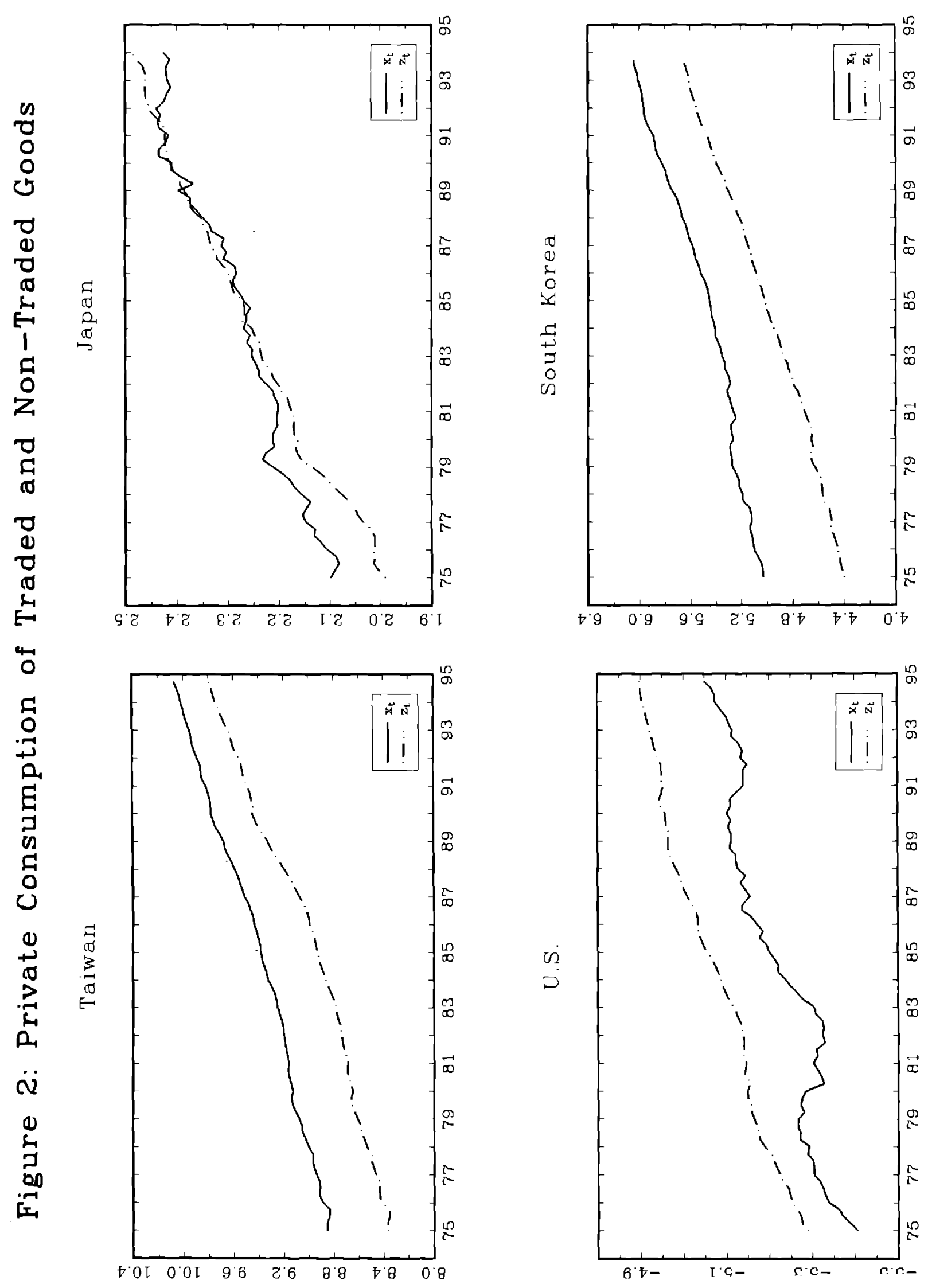

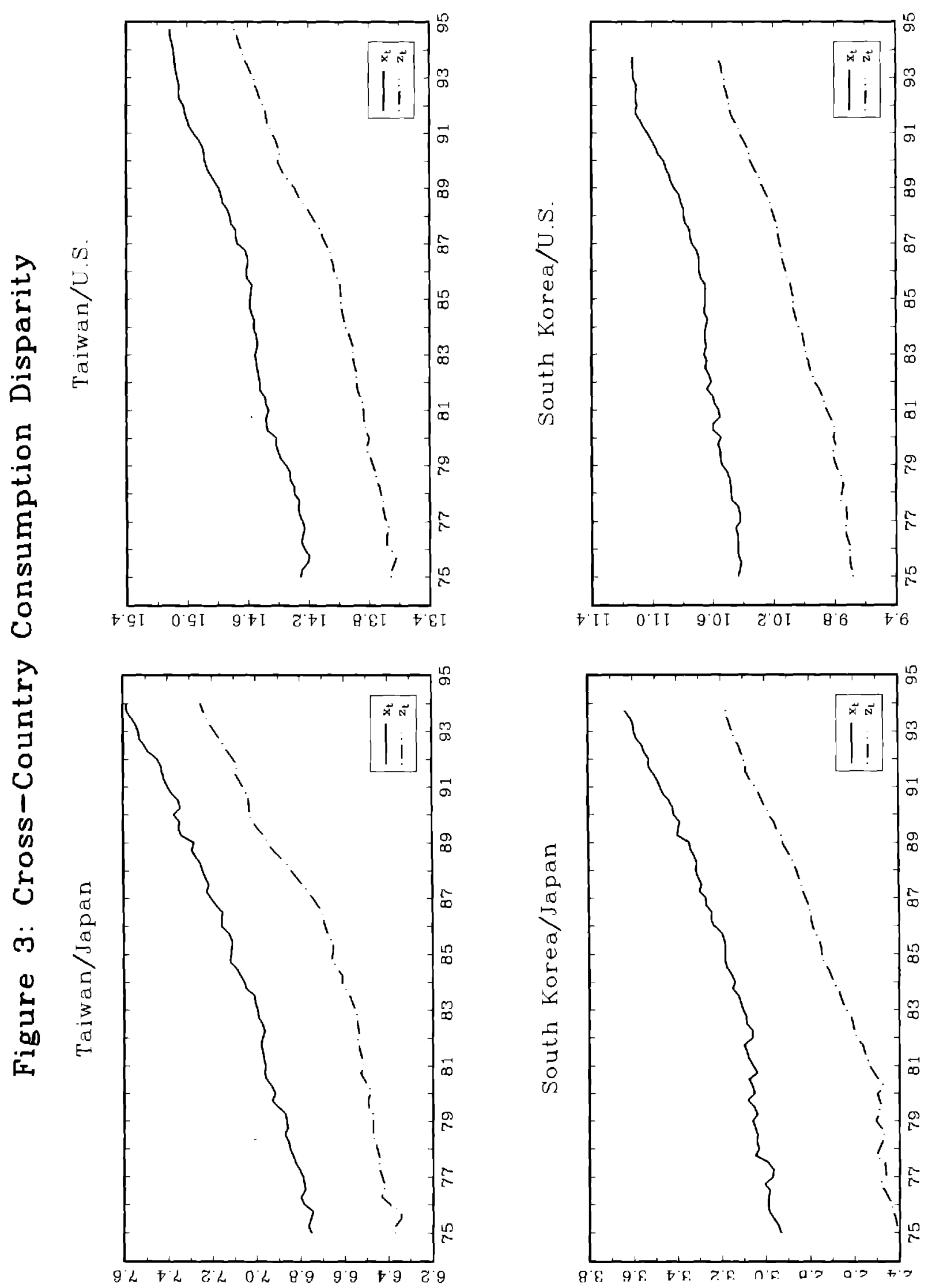
Table 1: Tests for Trend Property of Real Exchange Rate

\begin{tabular}{|c|c|c|c|c|}
\hline Statistics & Taiwan/Japan & Taiwan/USA & S. Korea/Japan & S. Korea/USA \\
\hline \multicolumn{5}{|c|}{ Price Index: CPI } \\
\hline \multicolumn{5}{|c|}{ Null: Difference Stationarity } \\
\hline$J(1,2)$ & $0.007^{*}$ & 0.397 & 0.026 & 0.257 \\
\hline$J(1,3)$ & $0.008^{* * * *}$ & 0.414 & $0.098^{*}$ & 0.484 \\
\hline$J(1,4)$ & $0.048^{* * *}$ & 1.144 & 0.341 & 3.194 \\
\hline \multicolumn{5}{|c|}{ Null: Difference Stationarity } \\
\hline$A D F(1)$ & -2.352 & -1.798 & -2.204 & -1.295 \\
\hline$A D F(2)$ & -2.628 & -1.936 & -2.571 & -1.583 \\
\hline$A D F(3)$ & -2.683 & -1.895 & -2.554 & -1.770 \\
\hline \multicolumn{5}{|c|}{ Null: Trend Stationarity } \\
\hline$G(1,2)$ & 0.135 & $5.586^{* *}$ & 0.487 & $3.628^{*}$ \\
\hline$G(1,3)$ & 0.171 & $5.750^{*}$ & 1.710 & $5.794^{*}$ \\
\hline$G(1,4)$ & 0.951 & $10.483^{* *}$ & 4.869 & $13.520^{* * *}$ \\
\hline \multicolumn{5}{|c|}{ Price Index: WPI } \\
\hline \multicolumn{5}{|c|}{ Null: Difference Stationarity } \\
\hline$J(\mathbf{1}, 2)$ & 0.053 & 0.168 & 0.193 & 0.028 \\
\hline$J(1,3)$ & $0.073^{*}$ & 0.248 & 0.226 & 0.164 \\
\hline$J(1,4)$ & $0.096^{* *}$ & 0.622 & 0.500 & 1.648 \\
\hline \multicolumn{5}{|c|}{ Null: Difference Stationarity } \\
\hline$A D F(1)$ & -2.612 & -1.894 & -2.331 & -1.822 \\
\hline$A D F(2)$ & -2.429 & -2.274 & -2.537 & -1.775 \\
\hline$A D F(3)$ & -2.673 & -2.469 & -2.694 & -1.885 \\
\hline \multicolumn{5}{|c|}{ Null: Trend Stationarity } \\
\hline$G(1,2)$ & 1.128 & $2.806^{*}$ & $3.098^{*}$ & 0.511 \\
\hline$G(1,3)$ & 1.509 & 3.871 & 3.538 & 2.598 \\
\hline$G(1,4)$ & 1.947 & $7.463^{*}$ & $6.395^{*}$ & $11.487^{* * *}$ \\
\hline
\end{tabular}

Note: $1 . J(p, q)$ and $G(p, q)$ denote Park and Choi's (1988) tests with the time polynomial of order $p$ in the null hypothesis and the time polynomial of order $q$ in the fitted regression.

2. $A D F(p)$ denotes Dickey and Fuller's (1984) test with the time polynomial of order 1 in the null hypothesis and $p$ lagged first difference terms in the fitted regression.

3. CPI and WPI denote consumer price index and wholesale price index, respectively.

4. * Significant at $10 \%$ level, ** Significant at $5 \%$ level, and *** Significant at $1 \%$ level. 
Table 2: Tests for Trend Property of Private Consumption

\begin{tabular}{|c|c|c|c|c|c|c|c|c|c|}
\hline \multirow[b]{2}{*}{ Statistics } & \multicolumn{6}{|c|}{ Null: Difference Stationarity } & \multicolumn{3}{|c|}{ Null: Trend Stationarity } \\
\hline & $J(1,2)$ & $J(1,3)$ & $J(1,4)$ & $A D F(1)$ & $A D F(2)$ & $A D F(3)$ & $G(1,2)$ & $G(1,3)$ & $G(1,4)$ \\
\hline & \multicolumn{9}{|c|}{ Japan } \\
\hline$\hat{x}_{t}$ & $0.008^{*}$ & $0.025^{* *}$ & 1.573 & -1.993 & -2.156 & -2.206 & 0.175 & 0.530 & $13.184^{* * * *}$ \\
\hline \multirow[t]{2}{*}{$\hat{z}_{t}$} & 1.063 & 1.153 & 1.323 & -1.760 & -2.296 & -2.066 & $10.105^{* * *}$ & $10.502^{* * *}$ & $11.165^{* *}$ \\
\hline & \multicolumn{9}{|c|}{ South Korea } \\
\hline$x_{t}$ & 2.331 & 2.346 & 9.972 & -1.041 & -1.126 & -1.438 & $12.407^{* * *}$ & $12.432^{* * *}$ & $16.115^{* * *}$ \\
\hline \multirow[t]{2}{*}{$z_{t}$} & 1.986 & 3.135 & 3.175 & -2.487 & -2.357 & -2.241 & $12.829^{* * *}$ & $14.622^{* * *}$ & $14.668^{* * *}$ \\
\hline & \multicolumn{9}{|c|}{ Taiwan } \\
\hline$x_{t}$ & 1.065 & 1.072 & 3.601 & -1.590 & -0.925 & -1.276 & $9.980^{* * * *}$ & $10.013^{* * *}$ & $15.144^{* * * k}$ \\
\hline \multirow[t]{2}{*}{$z_{t}$} & 2.131 & 2.179 & 6.300 & -1.106 & -0.769 & -1.446 & $12.723^{* * *}$ & $12.814^{* * *}$ & $16.132^{* * *}$ \\
\hline & \multicolumn{9}{|c|}{ United States } \\
\hline$\hat{x}_{t}$ & $0.000^{* * *}$ & 0.164 & $0.172^{*}$ & -1.563 & -1.922 & -2.106 & 0.000 & 2.730 & 2.843 \\
\hline$\dot{z}_{t}$ & 0.427 & 0.550 & 0.831 & -1.744 & -1.639 & -1.957 & $5.951^{* *}$ & $7.048^{* *}$ & $9.021^{* *}$ \\
\hline
\end{tabular}

Note: $1 . x_{t}$ and $z_{t}$ denote per capita real consumption on traded and nontraded goods, respectively.

2. ${ }^{*}$ Significant at $10 \%$ level, ${ }^{* *}$ Significant at $5 \%$ level, and ${ }^{* * *}$ Significant, at $1 \%$ level. 
Table 3: Testa for Cointegration

\begin{tabular}{|c|c|c|c|c|c|}
\hline \multicolumn{6}{|c|}{ Null: Cointegration } \\
\hline Variables & $H(0,1)$ & $H(0,2)$ & $H(1,2)$ & $H(1,3)$ & $H(1,4)$ \\
\hline \multicolumn{6}{|c|}{ South Korea / Japan } \\
\hline$\left(x_{t}, \hat{x}_{t}\right)$ & $3.154^{*}$ & $19.104^{* * * *}$ & $15.529^{* * *}$ & $15.538^{* * * *}$ & $16.676^{* * *}$ \\
\hline$\left(z_{t}, \hat{z}_{t}\right)$ & $14.361^{* * *}$ & $16.584^{* * * *}$ & $6.900^{* * *}$ & $10.029^{* * *}$ & $10.356^{* *}$ \\
\hline$\left(x_{t}, \hat{x}_{t}, z_{t}, \bar{z}_{t}\right)$ & 1.231 & $10.621^{\text {w***}}$ & $11.737^{* * * *}$ & $11.761^{* * *}$ & $17.770^{* * *}$ \\
\hline$\left(x_{t}-\hat{x}_{t}, z_{t}-\hat{z}_{t}\right)$ & 0.862 & $12.060^{* * * *}$ & $14.586^{* * *}$ & $14.690^{* * *}$ & $14.004^{* * *}$ \\
\hline$\left(q_{t}^{c}, x_{t}, \hat{x}_{t}, z_{t}, \hat{z}_{t}\right)$ & 1.136 & $5.078^{*}$ & $3.325^{*}$ & 3.339 & 3.491 \\
\hline$\left(q_{t}^{w}, x_{t}, \hat{x}_{t}, z_{t}, \hat{z}_{t}\right)$ & $2.872^{*}$ & $5.232^{*}$ & 1.834 & 2.085 & 2.367 \\
\hline$\left(q_{t}^{c}, x_{t}-\hat{x}_{t}, z_{t}-\hat{z}_{t}\right)$ & $4.671^{* *}$ & $4.833^{*}$ & 0.552 & 0.973 & 4.234 \\
\hline$\left(q_{t}^{w}, x_{t}-\hat{x}_{t}, z_{t}-\hat{z}_{t}\right)$ & $7.275^{* * *}$ & $7.326^{* *}$ & 0.019 & 1.695 & 4.309 \\
\hline \multicolumn{6}{|c|}{ South Korea / U.S. } \\
\hline$\left(x_{t}, \hat{x}_{t}\right)$ & $14.152^{* * *}$ & $17.612^{* * * *}$ & $14.819^{* * * *}$ & $14.932^{* * *}$ & $16.226^{* * *}$ \\
\hline$\left(z_{t}, \hat{z}_{t}\right)$ & $14.189^{* * *}$ & $16.994^{* * * *}$ & $12.207^{* * *}$ & $14.243^{* * *}$ & $14.632^{* * *}$ \\
\hline$\left(x_{t}, \hat{x}_{t}, z_{t}, \hat{z}_{t}\right)$ & $4.117^{* *}$ & $9.964^{* * *}$ & $7.764^{* * *}$ & $9.424^{* * *}$ & $12.677^{* * *}$ \\
\hline$\left(x_{t}-\hat{x}_{t}, z_{t}-\hat{z}_{t}\right)$ & 1.136 & $5.629^{*}$ & $4.003^{* *}$ & $8.967^{* *}$ & $11.601^{* * *}$ \\
\hline$\left(q_{t}^{c}, x_{t}, \hat{x}_{t}, z_{t}, \hat{z}_{t}\right)$ & 0.637 & 0.688 & 0.009 & 0.225 & 2.287 \\
\hline$\left(q_{t}^{w}, x_{t}, \hat{x}_{t}, z_{t}, \hat{z}_{t}\right)$ & 0.639 & 0.642 & 0.000 & 0.279 & 2.396 \\
\hline$\left(q_{t}^{c}, x_{t}-\dot{x}_{t}, z_{t}-\hat{z}_{t}\right)$ & 0.030 & 1.936 & 1.281 & 1.291 & 4.383 \\
\hline$\left(q_{t}^{w}, x_{t}-\hat{x}_{t}, z_{t}-\hat{z}_{t}\right)$ & $3.747^{*}$ & 4.253 & 0.597 & 0.961 & 3.491 \\
\hline \multicolumn{6}{|c|}{ Taiwan / Japan } \\
\hline$\left(x_{t}, \hat{x}_{t}\right)$ & $12.466^{* * *}$ & $20.772^{* * *}$ & $14.266^{* * *}$ & $14.357^{* * *}$ & $15.436^{* * *}$ \\
\hline$\left(z_{t}, \hat{z}_{t}\right)$ & $9.408^{* * *}$ & $16.151^{* * *}$ & $11.388^{* * *}$ & $11.396^{* * *}$ & $15.564^{* * *}$ \\
\hline$\left(x_{t}, \hat{x}_{t}, z_{t}, \hat{z}_{t}\right)$ & $2.842^{*}$ & 3.004 & 0.108 & 0.130 & 5.350 \\
\hline$\left(x_{t}-\hat{x}_{t}, z_{t}-\hat{z}_{t}\right)$ & $13.770^{* * *}$ & $14.074^{* * * *}$ & $4.987^{* *}$ & $7.893^{* *}$ & $8.720^{* *}$ \\
\hline$\left(q_{t}^{c}, x_{t}, \bar{x}_{t}, z_{t}, \bar{z}_{t}\right)$ & 0.397 & 1.320 & 0.493 & 0.651 & 1.438 \\
\hline$\left(q_{t}^{w}, x_{t}, \hat{x}_{t}, z_{t}, \dot{z}_{t}\right)$ & 0.818 & 1.811 & 0.527 & 1.071 & 2.671 \\
\hline$\left(q_{t}^{c}, x_{t}-\hat{x}_{t}, z_{t}-\bar{z}_{t}\right)$ & 0.069 & 0.133 & 0.019 & 0.083 & 2.839 \\
\hline$\left(q_{t}^{w}, x_{t}-\hat{x}_{t}, z_{t}-\hat{z}_{t}\right)$ & 0.320 & 0.752 & 0.068 & 0.371 & 2.978 \\
\hline \multicolumn{6}{|c|}{ Taiwan / U.S. } \\
\hline$\left(x_{t}, \hat{x}_{t}\right)$ & $16.968^{*+*}$ & $17.812^{* * *}$ & $13.980^{* * * *}$ & $13.980^{m m}$ & $15.998^{m+*}$ \\
\hline$\left(z_{t}, \bar{z}_{t}\right)$ & $9.136^{* * *}$ & $17.143^{* * *}$ & $13.803^{* * *}$ & $13.843^{* * *}$ & $15.588^{* * *}$ \\
\hline$\left(x_{t}, \hat{x}_{t}, z_{t}, \hat{z}_{t}\right)$ & 1.608 & 2.056 & 0.744 & 1.494 & 1.764 \\
\hline$\left(x_{t}-\hat{x}_{t}, z_{t}-\bar{z}_{t}\right)$ & $6.534^{* *}$ & $9.456^{* * *}$ & $3.393^{*}$ & $5.130^{*}$ & 5.132 \\
\hline$\left(q_{t}^{c}, x_{t}, \hat{x}_{t}, z_{t}, \hat{z}_{t}\right)$ & 1.316 & 2.159 & 0.360 & 0.720 & 0.723 \\
\hline$\left(q_{t}^{w}, x_{t}, \hat{x}_{t}, z_{t}, \hat{z}_{t}\right)$ & 1.306 & 2.808 & 0.798 & 1.848 & 2.594 \\
\hline$\left(q_{t}^{c}, x_{t}-\hat{x}_{t}, z_{t}-\hat{z}_{t}\right)$ & $6.756^{* * * *}$ & $6.914^{* *}$ & 0.488 & 1.666 & 1.828 \\
\hline$\left(q_{t}^{w}, x_{t}-\hat{x}_{t}, z_{t}-\hat{z}_{t}\right)$ & $2.953^{*}$ & 2.966 & 0.054 & 2.153 & 2.170 \\
\hline
\end{tabular}

Note: 1. $q_{t}$ denotes real exchange rate, $x_{t}$ and $z_{t}$ denote per capita real consumption on traded and nontraded goods, respectively-

2. * Significant at $10 \%$ level, ** Significant at $5 \%$ level, and *** Significant at $1 \%$ level. 
Table 4: Cointegrating Regressions of Real Exchange Rates on Private Consumption

\begin{tabular}{|c|c|c|c|c|}
\hline Equation & $\alpha_{x} \theta_{z}$ & $\hat{\alpha}_{x} \hat{\theta}_{z}$ & $\alpha_{z} \theta_{z}$ & $\hat{\alpha}_{z} \hat{\theta}_{z}$ \\
\hline \multicolumn{5}{|c|}{ South Korea/Japan } \\
\hline \multicolumn{5}{|c|}{ Price Index: CPI } \\
\hline $\begin{array}{l}\text { Equation (6) } \\
\text { Equation (7) }\end{array}$ & $\begin{array}{l}1.502^{*} / 1.462^{*} \\
1.669^{*} / 1.628^{*}\end{array}$ & $-0.686 /-0.804$ & $\begin{array}{l}2.778^{*} / 2.775^{*} \\
2.488^{*} / 2.452^{*}\end{array}$ & $1.159 / 1.057$ \\
\hline \multicolumn{5}{|c|}{ Price Index: WPI } \\
\hline $\begin{array}{l}\text { Equation (6) } \\
\text { Equation (7) }\end{array}$ & $\begin{array}{l}1.341^{*} / 1.267^{*} \\
1.241^{*} / 1.209^{*}\end{array}$ & $-0.591 /-0.786$ & $\begin{array}{l}3.546^{*} / 3.543^{*} \\
2.756^{*} / 2.728^{*}\end{array}$ & $1.298 / 1.113$ \\
\hline \multicolumn{5}{|c|}{$\begin{array}{c}\text { South Korea/U.S. } \\
\text { Price Index: CPI }\end{array}$} \\
\hline $\begin{array}{l}\text { Equation (6) } \\
\text { Equation (7) }\end{array}$ & $\begin{array}{l}2.657^{*} / 2.653^{*} \\
2.061^{*} / 2.057^{*}\end{array}$ & $1.477^{*} / 1.503^{*}$ & $\begin{array}{l}1.864^{*} / 1.826^{*} \\
1.625^{*} / 1.601^{*}\end{array}$ & $2.662^{*} / 2.767^{*}$ \\
\hline \multicolumn{5}{|c|}{ Price Index: WPI } \\
\hline $\begin{array}{l}\text { Equation (6) } \\
\text { Equation (7) }\end{array}$ & $\begin{array}{l}1.686^{*} / 1.682^{*} \\
1.427^{*} / 1.424^{*}\end{array}$ & $1.233^{*} / 1.236^{*}$ & $\begin{array}{l}1.728^{*} / 1.707^{*} \\
1.721^{*} / 1.700^{*}\end{array}$ & $2.425^{*} / 2.439^{*}$ \\
\hline \multicolumn{5}{|c|}{ Taiwan/Japan } \\
\hline \multicolumn{5}{|c|}{ Price Index: $C P I$} \\
\hline $\begin{array}{l}\text { Equation (6) } \\
\text { Equation (7) }\end{array}$ & $\begin{array}{l}-8.731^{*} /-8.476^{*} \\
-1.222 /-1.232\end{array}$ & $0.032 /-0.073$ & $\begin{array}{l}-5.225^{*} /-5.087^{*} \\
-0.342 /-0.331\end{array}$ & $3.770^{*} / 3.749^{*}$ \\
\hline \multicolumn{5}{|c|}{ Price Index: WPI } \\
\hline $\begin{array}{l}\text { Equation (6) } \\
\text { Equation (7) }\end{array}$ & $\begin{array}{l}-5.414^{*} /-5.331^{*} \\
-1.364 /-1.343\end{array}$ & $-0.476 /-0.498$ & $\begin{array}{l}-3.114^{*} /-3.068^{*} \\
-0.270 /-0.255\end{array}$ & $2.923^{*} / 2.964^{*}$ \\
\hline \multicolumn{5}{|c|}{ Taiwan/U.S. } \\
\hline \multicolumn{5}{|c|}{ Price Index: $C P I$} \\
\hline $\begin{array}{l}\text { Equation (6) } \\
\text { Equation (7) }\end{array}$ & $\begin{array}{c}-0.791 /-0.943 \\
0.657^{*} / 0.646^{*}\end{array}$ & $1.462^{*} / 1.475^{*}$ & $\begin{array}{l}-1.841^{*} /-1.945^{*} \\
-0.673^{*} /-0.700^{*}\end{array}$ & $2.784^{*} / 2.824^{*}$ \\
\hline \multicolumn{5}{|c|}{ Price Index: WPI } \\
\hline $\begin{array}{l}\text { Equation (6) } \\
\text { Equation (7) }\end{array}$ & $\begin{array}{l}0.149 /-0.064 \\
0.226 / 0.215\end{array}$ & $0.698^{*} / 0.741^{*}$ & $\begin{array}{l}-0.815 /-0.961 \\
-0.487^{*} /-0.512^{*}\end{array}$ & $2.078^{*} / 2.213^{*}$ \\
\hline
\end{tabular}

Note: * Significant at $5 \%$ level. 
Table 5: Cointegrating Regressions of Real Exchange Rates on Private Consumption and Government Consumption

\begin{tabular}{|c|c|c|c|c|c|c|}
\hline Equation & $\alpha_{x} \theta_{z}$ & $\hat{\alpha}_{x} \hat{\theta}_{z}$ & $\alpha_{z} \theta_{z}$ & $\hat{\alpha}_{z} \hat{\theta}_{z}$ & $\gamma$ & $\hat{\gamma}$ \\
\hline \multicolumn{7}{|c|}{ South Korea/Japan } \\
\hline \multicolumn{7}{|c|}{ Price Index: CPI } \\
\hline Equation (8) & $1.671^{*} / 1.655^{*}$ & $-0.774 /-0.832$ & $2.886^{*} / 2.743^{*}$ & $1.011 / 0.834$ & $-0.076 /-0.067$ & $-0.235 /-0.468$ \\
\hline Equation (9) & $1.214^{*} / 1.272^{*}$ & & $2.335^{*} / 2.348^{*}$ & & $0.227 / 0.182$ & \\
\hline \multicolumn{7}{|c|}{ Price Index: WPI } \\
\hline Equation (8) & $1.564^{*} / 1.513^{*}$ & $-0.629 /-0.746$ & $3.513^{*} / 3.285^{*}$ & $0.948 / 0.665$ & $-0.067 /-0.051$ & $-0.586 /-0.934$ \\
\hline Equation (9) & $0.785^{*} / 0.839^{*}$ & & $2.644^{*} / 2.658^{*}$ & & $0.233 / 0.192$ & \\
\hline \multicolumn{7}{|c|}{ South Korea/U.S. } \\
\hline \multicolumn{7}{|c|}{ Price Index: CPI } \\
\hline Equation (8) & $2.304^{*} / 2.327^{*}$ & $1.367^{*} / 1.306^{*}$ & $1.110^{*} / 1.171^{*}$ & $3.749^{*} / 3.585^{*}$ & $0.005 / 0.003$ & $0.912^{*} / 0.910^{*}$ \\
\hline Equation (9) & $1.611^{*} / 1.666^{*}$ & & $1.292^{*} / 1.343^{*}$ & & $0.299^{*} / 0.260^{*}$ & \\
\hline \multicolumn{7}{|c|}{ Price Index: WPI } \\
\hline Equation (8) & $1.536^{*} / 1.562^{*}$ & $1.311^{*} / 1.241^{*}$ & $1.437^{*} / 1.513^{*}$ & $3.091^{*} / 2.894^{*}$ & $-0.001 /-0.002$ & $0.239 / 0.240$ \\
\hline Equation (9) & $1.279^{*} / 1.295^{*}$ & & $1.677^{*} / 1.685^{*}$ & & $0.104^{*} / 0.091^{*}$ & \\
\hline \multicolumn{7}{|c|}{ Taiwan/Japan } \\
\hline \multicolumn{7}{|c|}{ Price Index: CPI } \\
\hline Equation (8) & $-9.457^{*} /-9.333^{*}$ & $3.070^{*} / 2.803^{*}$ & $-5.555^{*} /-5.495^{*}$ & $4.775^{*} / 4.690^{*}$ & $1.694^{*} / 1.588^{*}$ & $0.542 / 0.515$ \\
\hline Equation (9) & $0.440 / 0.286$ & & $0.838 / 0.785$ & & $1.066 / 1.029$ & \\
\hline \multicolumn{7}{|c|}{ Price Index: WPI } \\
\hline Equation (8) & $-5.715^{*} /-5.635^{*}$ & $1.534^{*} / 1.365^{*}$ & $-3.316^{*} /-3.255^{*}$ & $3.591^{*} / 3.471^{*}$ & $0.818^{*} / 0.794^{*}$ & $0.362 / 0.347$ \\
\hline Equation (9) & $0.148 / 0.051$ & & $0.619 / 0.584$ & & $0.633 / 0.621$ & \\
\hline \multicolumn{7}{|c|}{ Taiwan/U.S. } \\
\hline \multicolumn{7}{|c|}{ Price Index: CPI } \\
\hline Equation (8) & $-0.451 /-0.569$ & $2.111^{*} / 2.114^{*}$ & $-1.645^{*} /-1.755^{*}$ & $3.653^{*} / 3.716^{*}$ & $-0.163 /-0.231$ & $-0.672^{*} /-0.611^{*}$ \\
\hline Equation (9) & $0.912^{*} / 0.908^{*}$ & & $-0.620^{*} /-0.635^{*}$ & & $-0.260 /-0.257$ & \\
\hline \multicolumn{7}{|c|}{ Price Index: WPI } \\
\hline Equation (8) & $0.693 / 0.604$ & $1.847^{*} / 1.830^{*}$ & $-0.644 /-0.708$ & $3.561^{*} / 3.565^{*}$ & $-0.406^{*} /-0.426^{*}$ & $-1.029^{*} /-0.992^{*}$ \\
\hline Equation (9) & $0.783^{*} / 0.775^{*}$ & & $-0.352 /-0.370$ & & $-0.557^{*} /-0.529^{*}$ & \\
\hline
\end{tabular}

Note: 1. * Significant at $5 \%$ level.

2. Sample period: 1975:1-1993:4. 